https://helda.helsinki.fi

Policies for older volunteers: A study of Germany and Italy, 1990-2008

\author{
Komp, Kathrin
}

2013

Komp , K , Van Kersbergen, K \& Van Tilburg , T 2013 , ' Policies for older volunteers: A study of Germany and Italy, 1990-2008 ' , Journal of Aging Studies , vol. 27 , no. 4 , pp. 443-55 . https://doi.org/10.1016/j.jaging.2013.10.003

http://hdl.handle.net/10138/155395

https://doi.org/10.1016/j.jaging.2013.10.003

acceptedVersion

Downloaded from Helda, University of Helsinki institutional repository.

This is an electronic reprint of the original article.

This reprint may differ from the original in pagination and typographic detail.

Please cite the original version. 


\title{
Policies for older volunteers: A study of Germany and Italy, 1990-2008
}

\author{
Kathrin Komp *, Kees van Kersbergen ${ }^{1}$, Theo van Tilburg \\ Faculty of Social Sciences, VU University Amsterdam, De Boelelaan 1081, 1081 HV Amsterdam, The Netherlands
}

\section{A R T I C L E I N F O}

\section{Article history:}

Received 13 May 2013

Received in revised form 17 October 2013

Accepted 17 October 2013

\section{Keywords:}

Old age

Volunteering

Policies

Discourse

Germany

Italy

\begin{abstract}
A B S T R A C T
Older people increase their well-being and contribute to the community when they volunteer. Therefore, policy-makers sometimes consider supporting older volunteers. However, they reach different conclusions on whether they should introduce policies for older volunteers, and on what policy would be the most suitable. This article studies how policies for older volunteers emerged in Germany and Italy, both countries having one of the oldest populations in the world. It explores the political discourse on older volunteers, and how this discourse translates into policies. To do this, the article presents data collected in expert interviews and document analysis. Findings show that German policy-makers stress the contribution of volunteering to older people's well-being and have introduced policies for older volunteers. Italian policy-makers, in contrast, frame older volunteers as social service providers and have decided not to single out specific age groups in their policies for volunteers. Moreover, the policies are influenced by the policy-makers' perceptions and path-dependencies, meaning policies and institutions that were introduced in the past. These findings suggest that whether or not policies for older volunteers emerge depends less on the characteristics of the older population and more on the society and its political traditions.
\end{abstract}

(c) 2013 Elsevier Inc. All rights reserved.

\section{Introduction}

Population aging and the economic crisis have changed the face of welfare states. These states have had to accommodate the needs of an aging population while cutting their expenditures (Komp \& Béland, 2012). For a long time, policy-makers considered this task highly problematic because they assumed that population aging would increase the need for health services and pension benefits. Moreover, they assumed that this increased need would drive welfare state expenditures and drain public funds (Walker, 2000). However, we now know that these assumptions oversimplify the situation.

\footnotetext{
* Corresponding author at: Department of Sociology, Umea University, 90187 Umea, Sweden. Tel.: + 46907865457.

E-mail addresses: kathrin.komp@soc.umu.se (K. Komp), kvk@ps.au.dk (K. van Kersbergen), T.G.van.Tilburg@vu.nl (T. van Tilburg).

${ }^{1}$ Present address: Department of Political Science and Government, Aarhus University, Bartholins Allé 7, 8000 Aarhus C, Denmark.
}

Aging populations in Western countries comprise many healthy older people, which bring a new challenge to welfare states. Those healthy older people are self-dependent and possibly active. They do not need support through health services. Instead, they put a new welfare need on the political agenda: the quest for meaningful activities in later life (Laslett, 1996; Van den Heuvel, 1997). When engaging in such activities, older people experience a sense of meaning, increased well-being, and stronger social integration (Fraser, Clayton, Sickler, \& Taylor, 2009; Putnam, 2000). Consequently, older people may consider it a need to engage in meaningful activities, such as volunteering, life-long learning, or looking after their grandchildren (Laslett, 1996). In their efforts to ensure well-being, policy-makers in welfare states have to consider this need (Barr, 2004; Esping-Andersen, 1990).

When policy-makers act upon the welfare needs of healthy older people, they may "kill two birds with one stone." In addition to supporting older people, they can enact 
austerity policies that counter the effects of population aging and economic crises. This twofold effect arises because some activities are beneficial to older people and to welfare states. Voluntary engagement, in particular, has such an effect. When older people volunteer, they may carry out tasks that would otherwise fall to public social services. Consequently, the demand for public social services could drop, which would ultimately reduce public spending (Erlinghagen, 2010; Minkler \& Holstein, 2008). This way, older volunteers may provide policy-makers with a cost-saving opportunity. Considering the benefits for both older people and welfare states, it seems only logical that policy-makers support volunteering in old age (Komp, 2011).

In practice, many policy-makers consider introducing policies for older volunteers. They consider whether such policies are necessary, and which policies would be suitable. The conclusions these policy-makers reach differ widely. For example, American policy-makers established federal programs for older volunteers as early as the 1960s (Chambre, 1993). Moreover, the U.S. government subsidizes organizations with senior-specific volunteering programs (Baldock, 1999). Australian policy-makers support older volunteers to a limited extent. National policies in Australia focus only on those older volunteers who seek to re-enter the labor market through their voluntary engagement, while state policies subsidize a few programs for older volunteers, which the states view as organized leisure activities (Baldock, 1999; Warburton, Paynter, \& Petriwskyi, 2007). Dutch policy-makers, finally, decided against policies for older volunteers, considering such policies as ageism. Instead, they subsidize volunteer programs that target all ages (Baldock, 1999).

Previous studies revealed remarkable variation in policies for older volunteers. However, these studies did not identify any pattern to why some governments introduce such policies, while others do not. Neither did these studies identify any pattern to how governments decide on the kind of policy, such as the introduction of subsidies, model programs, or legislation. This lack of knowledge prevents us from drawing conclusions from the few existing countrystudies to those countries that have not yet been studied. Consequently, researchers and policy-makers have few models of good practice to learn from. The study at hand aims to help fill this gap.

This article investigates policies for older volunteers in Germany and Italy. On the one hand, it studies whether such policies exist and if yes, what they contain. These questions are interesting, because Germany and Italy are likely to be models of good practice. Surpassed only by Japan, these countries hold the oldest populations in the world (United Nations, 2009), which makes old age policies vital to them. Moreover, both countries are in Europe, where welfare states are comparatively large in scope (Alesina \& Glaeser, 2004). Therefore, policy-makers in both countries will consider policies facilitating older peoples' well-being. Finally, both welfare states are based on the subsidiarity principle, which calls for governments to intervene only after citizens have failed to solve problems by themselves, e.g. through volunteering (Sundström et al., 2008). Therefore, policy-makers in these countries are likely to consider old age in conjunction with questions of volunteering. On the other hand, this article explores why policy-makers decide (not) to support older volunteers. The answer to this question is interesting, because it provides a starting point for explaining country-differences in policies for older volunteers. Additionally, it informs political parties and lobby groups when and how they should best become active to influence policy-making for older volunteers.

The article is structured as follows. First, it introduces Germany and Italy as the settings of this study. It describes both countries in terms of their policies for volunteers of all ages, and in terms of their older citizens' engagement in volunteering. Then, it describes the process of data collection and analysis utilizing the policy cycle model, which understands policy-making as a sequence of stages (Dye, 2008). Subsequently, it presents the findings according to the policy cycle model. Finally, this article discusses the findings in terms of their scientific and practical relevance.

\section{Policies for volunteers of all ages in Germany and Italy}

Volunteering plays an important role for German and Italian governments. Policies in both countries are based on the subsidiarity principle, which means that governments should value and preserve their citizens' self-help potential. The assumption is that, when given the opportunity, citizens can often solve or at least diminish their own social problems. Governments should only intervene once this self-help potential has been exhausted (Evers \& Laville, 2004; Sundström et al., 2008). Consequently, German and Italian governments try to facilitate their citizens' problem-solving capacities, for example, by leaving room for voluntary activities.

Like in many countries, policy-makers in Germany and Italy often consider volunteers a "third sector". The term "third sector" stems from the idea that welfare emerges from the contributions of several actors, who interact to create a welfare mix (Evers, 1995). In this welfare mix, governmental actors represent a first, economic actors a second, voluntary actors a third, and the family a fourth sector (Ascoli \& Ranci, 2002; Evers, Pijl, \& Ungerson, 1994). The third sector subsumes all non-profit associations, which are often active in the areas of sports, culture, leisure, and charity. Among third-sector organizations, especially welfare associations catch the eye of policy-makers. Welfare associations usually aim to provide help and care to people in need, for example, individuals with disabilities, or older people. These associations are usually based on religious, charitable, or humanitarian ideas, and many of them date back more than a century. Prime examples of welfare associations are Caritas and the Red Cross. German and Italian policy-makers are particularly interested in supporting welfare associations, because they facilitate the provision of help care to vulnerable citizens (Evers, 1995; Laville, 2008).

\section{Policies for volunteers of all ages in Germany}

In Germany, policies for volunteers are institutionalized in legislation, committees dealing with the topic of volunteering, and support programs. Support for volunteers is mentioned in two German laws. First, support for welfare associations is regulated in $\S 5$ of the Sozialgesetzbuch XII, which is the legislation that regulates social security. Paragraph 5 of this statute specifies how public agencies and welfare 
associations should interact when providing social and welfare services. This paragraph states that public agencies should not provide social and welfare services that welfare associations already provide. Moreover, public agencies should support and cooperate with welfare associations. The regulations of the Sozialgesetzbuch XII and its predecessors guaranteed the support of German governments for welfare associations throughout our entire study period (Bonker \& Wollmann, 1996). Second, support for volunteering is also institutionalized in German tax regulations. Paragraph 52 of the Abgabenordnung-the German tax code-mentions tax exemptions for public utility associations. Associations can obtain public utility status if they are non-profit, and if they aim to support the general public physically, intellectually, or morally. They can do this, for example, by engaging in sports, culture, or volunteering. Many volunteer associations in Germany reach the public utility status and, therefore, benefit from the tax exemptions.

In addition to the legal support for volunteers, federal, regional, and local governments also installed committees to facilitate volunteering. Among these committees, the ones associated with the "Study Commission on the Future of Civic Engagement" are particularly interesting. The German parliament formed the study commission in 1999 to prepare for the International Year of Volunteers 2001. The study commission discussed possibilities to facilitate volunteering until 2002. Since then, many actors in Germany strived to implement the insights generated by this commission. For example, the German parliament formed a sub-commission on civic engagement. Several actors, including federal and regional governments, also joined forces to create a nationwide network on civic engagement in 2002 (Deutscher Bundestag, 2007). In all these discussions, policy-makers used the term civic engagement instead of volunteering to signal a new character for voluntary activities. This character of volunteering is distanced from its charity-based roots, and instead builds on the idea of civic participation (Alscher, Dathe, Priller, \& Speth, 2009).

Finally, German governments at the federal, regional, and local levels institutionalized their support for voluntary activities in manifold ways, such as programs, projects and networks. These support efforts are very diverse and heterogeneous-even more so than the institutionalized support for older volunteers in Germany that we previously described. We will therefore content ourselves with the statement that such support exists at all governmental levels, and refer the interested reader to the excellent overview report of Alscher et al. (2009).

\section{Policies for volunteers of all ages in Italy}

Italian policies institutionalized various forms of support for volunteers. Like in Germany, in Italy this support is particularly strong for volunteer associations that provide social services. Compared to Germany, however, this support developed more dramatically in Italy since the early 1990s.

The development of policies for volunteers in Italy took off in 1991, when a law regarding volunteer associations and another regarding social cooperatives were enacted. These laws were the first to regulate the activity of non-profit organizations, and they enabled such organizations to receive public funding for the delivery of social services (Borzaga \& Fazzi, 2011). Before 1991, the landscape of volunteer organizations in Italy was fragmented and the organizations were usually associated with either the Catholic Church or the socialist communist party (Zimmer \& Evers, 2010). The introduction of the legislation in 1991 allowed organizations to develop without such ideological affiliations. Consequently, the voluntary sector started to develop and diversify rapidly. The blooming of this sector was further facilitated by later laws, such as the framework law on social promotion associations in 2000 (Borzaga \& Fazzi, 2011).

When Italian policies support volunteer associations, they often consider these associations as social service providers. In fact, the trigger for support efforts was a 1990 law that allowed local authorities to contract out social services (Borzaga \& Fazzi, 2011). In the wake of this legislation, Italian governments tried to help volunteer associations to take on the role of social service providers. The Italian state traditionally holds back on providing such services and instead financially supports service providers and users (Ascoli, Pavolini, \& Ranci, 2002). Italian governments, moreover, got volunteer associations more strongly involved in the management of and policy planning for social services (Ranci \& Montagnini, 2010). Part of this increased involvement is that representatives of the Third Sector Forum (Forum Terzo Settore)-an association of third sector organizations-were appointed to the National Council on Economy and Work (Ranci, Pellegrino, \& Pavolini, 2005).

Finally, there are policies for older volunteers in Italy that do not address social service provision. Most notably, governments installed the Centri di Servizio per il Volontariato (CSV, "Service Centers for Volunteering") in 1997 to provide volunteer organizations with funding and support services (Borzaga, 2004; Ranci \& Montagnini, 2010). The activity levels of the CSVs differ across regions, with cities in central and northern Italy being the most supportive and active locations. Additionally, Italian policy-makers set up the National Observatory for Volunteering (Osservatorio Nazionale per il Volontariato) at the Federal Ministry for Work and Social Policy. This observatory serves as a discussion forum for umbrella organizations of volunteer associations, policymakers, researchers, and trade unions (Ranci et al., 2005). However, the outcomes of the work of the observatory have a purely informational function.

\section{Older volunteers in Germany and Italy}

When scholars talk about older volunteers, they may be referring to two slightly different groups of people. First, they may refer to older individuals who do unpaid work for organizations, such as sports clubs or welfare associations. This kind of volunteering is sometimes referred to as formal volunteering (Mutchler, Burr, \& Caro, 2003). Second, they might have all those older individuals in mind who do unpaid work inside or outside of organizations. They would, therewith, refer to the wider group of older formal and informal volunteers. Informal volunteers can be active in any number of contexts, for example, neighborly help or help to other members of the community (Van Tienen, Scheepers, Reitsma, \& Schilderman, 2011). This range of possible contexts makes informal volunteering not only a wide-spread, but also a diffuse, phenomenon. Volunteering might go unnoticed 
because it blends in with other everyday activities, and has fuzzy boundaries with acts of friendship and help to kin (Choi, Burr, Mutchler, \& Caro, 2007). The question of boundaries is even more pressing in Italy than in Germany, because Italians have more extensive and strongly used family ties (Alesina \& Giuliano, 2010; Hollinger \& Haller, 1990). As a consequence of the diffusiveness of informal volunteering, governments usually concentrate their support on formal volunteering. We will follow the same logic and understand volunteering as "unpaid work for organizations" for the remainder of this article.

Previous studies showed that the volunteering behavior of older Germans and older Italians differs (e.g. Dekker \& Van den Broek, 2005; Hank \& Stuck, 2008). Older Germans volunteer slightly more often than most of their European counterparts. In $2004,10 \%$ of the German population aged 50 years and older volunteered. In that year, the Western European average was also at $10 \%$. In 2006, however, the average of older German volunteers increased to $13 \%$, while the Western European average increased to only $11 \%$. In contrast to Germany, the rate of older volunteers in Italy is below the European average. In 2004 the volunteer rate for older individuals in Italy was 7\%, and in 2006 it had increased by $1 \%$ only (Hank \& Erlinghagen, 2010).

The numbers of older volunteers become more indicative when we consider it in the national context. In Western Germany, the general volunteering rate dropped from 14 to $8 \%$ of the population from 1981 to 2000 (Dekker \& Van den Broek, 2005). This means that older volunteers constituted an increasing share of this shrinking group of volunteers. Older people, therefore, seem to be the social group on which volunteering increasingly relies. In Italy, by contrast, the rate of volunteers in the total population increased from 12 to $16 \%$ between 1981 and 2000 (Dekker \& Van den Broek, 2005). This means that older volunteers are losing some of their relevance to Italy's voluntary sector, because individuals from all age groups have become more engaged in volunteering.

Besides the number, the characteristics of older volunteers also differ slightly between Germany and Italy. The average older volunteer in both countries is female, healthy, and well educated, and wants to be useful. However, pleasure is a stronger motivating force for German than for Italian volunteers. Almost 70\% of older German volunteers reported to enjoy volunteering, while only about $30 \%$ of their Italian counterparts reported this sentiment (Erlinghagen \& Hank, 2006). Moreover, religion is a stronger motivation force among older Italian volunteers, while social reasons and personal satisfaction are more important for older German volunteers (own analysis of data from the 1990 World Values Survey). These numbers suggest that volunteering plays a country-specific role in the lives of older people. While it is strongly associated with self-fulfillment and social contacts in Germany, social and religious obligations are influential in Italy.

\section{Studying policies for older volunteers}

Studying policies for older German and Italian volunteers is a challenging task, because there is little extant knowledge to build on and only a few guiding examples to follow (e.g. Baldock, 1999; Leonard \& Johansson, 2008). However, the few existing studies on policies for older volunteers give valuable insight into research strategies. These studies relied on an array of sources to collect the information they needed, with the most important sources being expert interviews and policy documents such as laws and governmental reports (Baldock, 1999; Chambre, 1993; Warburton \& Cordingley, 2004). The studies, moreover, revealed a wide range of possible key players, and levels of analysis that have to be considered (e.g. Baldock, 1999; Chambre, 1993; Leonard \& Johansson, 2008). Taken together, these insights suggest that a suitable research strategy has to be flexible and adaptable. It has to be able to explore country-specific structures and logics in policies for older volunteers, and it has to be able to detect and analyze country-specific information sources.

\section{Data collection}

To ensure openness and flexibility, we chose a mixedmethods approach based on theoretical sampling for this study. Mixed-methods approaches combine several research methods (Johnson, Onwuegbuzie, \& Turner, 2007; Morse, 2009), allowing us to use all the information sources we identify during the course of our study. Theoretical sampling is a qualitative research approach that is particularly suitable for topics about which little is known. In this sampling process, researchers change back and forth between collecting and analyzing their data. They use the findings from each step of data analysis to inform the next step of data collection. If the data analysis reveals knowledge gaps, then the researchers design a step of data collection that fills those gaps. If the sample converges, meaning if the data analysis does not generate additional information or reveal knowledge gaps, then the researchers consider the topic sufficiently studied. Consequently, they stop collecting new data (Glaser \& Strauss, 2006). This way, the sampling process evolves with the information the researchers discover.

Resembling the research approaches of previous studies, our research strategy also led to an analysis that mainly centered on expert interviews and analyses of policyrelevant documents. In the initial stage of the analysis, we reviewed literature. Then, we analyzed policy documents and conducted expert interviews. The policy documents that we analyzed are legislation and publications of local, regional, and national governments and of political parties, which address either older people or volunteers. The experts we interviewed are people involved in or observing political processes concerning old age or volunteering: policy-makers, policy consultants, researchers and board members of associations concerned with volunteering or old age. The experts were active at the national, regional, and local levels. From both types of sources, we collected information on the period between 1990 and 2008. We begin with the early 1990 s because this is when discussions about older volunteers gained ground (e.g., Bass, Caro, \& Chen, 1993; Kohli \& Künemund, 1996).

In total, we collected information from two pieces of legislation, four series of publications and sixteen experts in Germany and from two pieces of legislation, four series of publications and eleven experts in Italy before our samples converged. We collected information from the German experts through face-to-face interviews, from April to June 
2009. We collected information from ten of the eleven Italian experts through face-to-face interviews and from one through a written questionnaire, during March and April 2009. Tables 1 and 2 provide a list of the documents we analyzed and of the experts we consulted.

All interviews were structured similarly. Initially, we collected information on personal experiences with governmental support for older volunteers. Then, we discussed with the interviewees the information we had collected until then. Finally, we asked for suggestions on relevant literatures, potential interview partners and phenomena that we could investigate. We also analyzed the literatures suggested.

\section{Data analysis}

We analyzed the interviews and documents in a qualitative content analysis. This kind of analysis summarizes and structures information based on categories found in the text. Following Mayring (2008), we started by summarizing each interview and policy document separately and then collected additional information to clarify ambiguous passages. Finally, we brought the information from the different interviews and documents together to create a single comprehensive narrative. To ensure that our interpretations were correct, we sought feedback on this narrative from German and Italian researchers.

Table 1

Sources of information in Germany.

\begin{tabular}{ll}
\hline Type of information & List of information sources consulted \\
source & \\
\hline Texts of law & - Abgabenordnung [Tax Code] \\
& - Sozialgesetzbuch XII [Book of social law XII] \\
Series of publications & - National reports on volunteering (1999, 2004) \\
& - National reports on old age (1993, 1998, 2001, \\
& 2002, 2005) \\
& - Information bulletin of the city council of \\
& Frankfurt upon Main (1990-2008) \\
& - Information bulletin on participation of the \\
& Ministry for Work, Social Issues and Health of \\
& the state Schleswig-Holstein (2004-2008) \\
& - An officer for senior citizens within the Federal \\
& Ministry for Family Affairs, Senior Citizens, \\
& Women and Youth (BMFSFJ) \\
& - A former minister of the BMFSFJ \\
& - Two coordinators of project for older \\
& volunteers (one from Eastern, one from Western \\
& Germany) \\
& - Two representatives of state-projects \\
& supporting older volunteers (one from Hessia, \\
& one from Baden-Wuerttemberg) \\
& - Two representatives of the pilot projects \\
& installed by the federal ministry of family \\
& (one from “Agencies for Senior Citizens," one \\
& from “Experiential Knowledge for Initiatives") \\
& - Three representatives of the senior councils \\
& (at the local, regional, and national levels) \\
& - Two researchers who helped to implement the \\
& BMFSFJ pilot projects on older volunteers \\
& - A researcher specialized in volunteering \\
& - A researcher who is part of the advisory group \\
& on old age within the BMFSFJ \\
& - A researcher who co-authored the latest \\
& national report on volunteering \\
& \\
\hline &
\end{tabular}

Table 2

Sources of information in Italy.

\begin{tabular}{|c|c|}
\hline $\begin{array}{l}\text { Type of information } \\
\text { source }\end{array}$ & List of information sources consulted \\
\hline Texts of law & $\begin{array}{l}\text { - Two national texts of law on voluntary } \\
\text { associations (266/1991 and 328/2000) }\end{array}$ \\
\hline Series of publications & $\begin{array}{l}\text { - National reports on volunteering (1998, 2001, } \\
\text { 2006) } \\
\text { - National reports on old age (1991-2003) } \\
\text { - Bulletin of the regional council of the province } \\
\text { Tuscany (1990-2007) } \\
\text { - Social reports of the province Bolzano-Alto } \\
\text { Adige (1994-2007) }\end{array}$ \\
\hline Experts & $\begin{array}{l}\text { - A member of the National Observatory for } \\
\text { Volunteering } \\
\text { - An assessor (equivalent to a minister) of the } \\
\text { province Marche } \\
\text { - An officer for senior citizens in the department } \\
\text { for social affairs of the province Bolzano Alto } \\
\text { Adige } \\
\text { - Two representatives of AUSER (one active at } \\
\text { the local and regional levels, one active at the } \\
\text { national level) } \\
\text { - A representative of the Centri di Servizio per il } \\
\text { Volontariato (active at the local and regional } \\
\text { levels) } \\
\text { - Two researchers specializing in older } \\
\text { volunteers } \\
\text { - A researcher specializing in volunteering in } \\
\text { general } \\
\text { - A researcher specializing in old age } \\
\text { - A researcher from the National Centre for } \\
\text { Volunteering }\end{array}$ \\
\hline
\end{tabular}

We structure the findings according to the policy cycle model (see Fig. 1), which suggests that policy-making occurs in a sequence of stages. In the first stage, situations or phenomena-such as older volunteers-attract the attention of policy-makers. In the second stage, policy-makers consider intervening. If this consideration leads to favorable results, policy-makers subsequently become active in a third stage, for example, by introducing policies for older volunteers. Afterwards, policy-makers evaluate and possibly reformulate their policies. This evaluation and reformulation re-starts the policy cycle (Jann \& Wegrich, 2007).

In this study, we will focus on the first three stages of the policy-cycle, which culminate in the introduction of policies. The first stage reveals whether and why older volunteers attract the attention of policy-makers. Kingdon (1995) suggested that both participants in policy-making and features of an issue can command the attention of policy-makers. Participants in policy-making are, for example, interest groups and political parties. Hogwood and Gunn (1984) specified six ways in which features of an issue can command the attention of policy-makers. First, the issue reaches critical proportion. This could, for example, happen when the number of older volunteers increases. Second, the issue becomes visible due to a particular incident. For example, volunteering became more visible when the United Nations declared 2001 the International Year of Volunteers (Haski-Leventhal, Meijs, \& Hustinx, 2010). Third, the issue has an emotional quality, which attracts media coverage. This quality could stem from the health benefits gained from volunteering in later life ( $\mathrm{Li} \&$ Ferraro, 2006). Fourth, the issue promises to have wide impact. Volunteering in later life could have such an impact, 


\begin{tabular}{|c|c|c|}
\hline $\begin{array}{l}\text { Topic attracts } \\
\text { attention }\end{array}$ & $\begin{array}{l}\text { Policy-makers } \\
\text { consider policy }\end{array}$ & $\begin{array}{l}\text { Policy-makers } \\
\text { introduce policy }\end{array}$ \\
\hline $\begin{array}{l}\text { Participants } \\
\text { command attention } \\
\text { - Interest groups, } \\
\text { political parties, etc. } \\
\\
\text { Topic commands } \\
\text { attentions: } \\
\text { - Critical proportion } \\
\text { - Visibility in } \\
\text { particular incident } \\
\text { - Emotional quality } \\
\text { - Wide impact } \\
\text {-Tackles question } \\
\text { about distribution } \\
\text { of power } \\
\text { - Fashionability }\end{array}$ & $\begin{array}{l}\text { Considerations: } \\
\text { - Need for policy } \\
\text { - Possibility of } \\
\text { policy } \\
\text { - Standing of the } \\
\text { policy }\end{array}$ & $\begin{array}{l}\text { Result: } \\
\text { - Policies for older } \\
\text { volunteers } \\
\text { - Policies for all } \\
\text { volunteers } \\
\text { - No policies for } \\
\text { volunteers }\end{array}$ \\
\hline
\end{tabular}

Fig. 1. Framework for the analysis. Part of the policy cycle model that describes why a topic attracts the attention of policy-makers, why policy-makers consider introducing policies, and what policies for older volunteers they might introduce.

because it increases social cohesion (Putnam, 2000). Fifth, the issue tackles questions about the distribution of power in a society. In our case, older peoples' power changed because of their contribution to welfare (Laslett, 1996). Sixth, the issue is fashionable. Volunteering in later life could be considered fashionable in discussions about citizens' responsibilities (Fuller, Kershaw, \& Pulkingham, 2008).

When we turn our attention to the second stage of the policy cycle model, we discover how policy-makers decide whether or not to introduce policies after older volunteers have attracted their attention (Howlett, Ramesh, \& Perl, 2009). Previous studies identified three factors that influence this choice: need, possibility, and standing. With the first factor, policy-makers are likely to introduce policies when their ideal situation is not reached (Dery, 1984), that is, when the number of older volunteers is low (Hong, MorrowHowell, Tang, \& Hinterlong, 2009; Pavolini \& Ranci, 2008). With the second, policy-makers introduce policies where they see concrete possibilities to exert influence (Jann \& Wegrich, 2007; Kingdon, 1995). Their judgment of the possibilities might depend on existing policies for volunteers of all ages. Finally, with the third, policy-makers choose a policy that is of good standing in their electorate and their political party (Béland, 2005; Dery, 1984). The electorate might frown upon support for older volunteers because there are normative ideas in Western societies that old age should be free from productive activities (Kohli, 1991). Acting against these ideas might be perceived as unjust and consequently cause opposition. Public protest and losses in upcoming elections could result (Vis \& Van Kersbergen, 2007). However, support for older volunteers may just as well have a positive symbolic effect on older citizens. Such an effect occurs when the contributions of volunteering to well-being and self-realization are stressed, making policies for older volunteers appear as a service to older people.

The third stage of the policy-model stands for concrete policies. These policies might explicitly target older volunteers, for example, through model programs or funding that is specifically dedicated to these volunteers. The policies might also target volunteers of all ages and, thereby benefit older volunteers indirectly. An example of this kind of policy is a tax exemption for volunteer associations (Lynn, 2002). Finally, policy-makers might have decided not to introduce policies for older volunteers. Reasons might be a conscious decision against such policies, or the idea that withholding support facilitates independent initiatives (Chambre, 1989; Jeppson Grassman \& Svedberg, 1996).

\section{Findings from Germany}

Germany has a history of policies on older volunteers, which are surrounded by vivid discussions on volunteering in old age. The following sections present these discussions and policies. Fig. 2 provides an overview.

\section{How the topic attracts attention in Germany}

German policy-makers have been paying attention to older volunteers throughout our entire study period, from 1990 to 2008. The roots of this attention go back to the late 1980s, when Chancellor Helmut Kohl appointed Ursula Lehr as Federal Minister for Youth, Family Affairs, Women and Health. Lehr was a professor of gerontology, and she stressed the situation of older people during her term in office (1988-1991). She laid the groundwork for the first pilot project supporting older volunteers in Germany, which was 


\begin{tabular}{|c|c|c|}
\hline $\begin{array}{l}\text { Topic attracts } \\
\quad \text { attention } \\
\text { Participants attract } \\
\text { attention: } \\
\text { - Policy-makers: } \\
\text { personal } \\
\text { preferences } \\
\text { Topic attracts } \\
\text { attention: } \\
\text { - Critical proportion } \\
\text { reached: older } \\
\text { people } \\
\text { - Tackles question } \\
\text { about distribution } \\
\text { of power: grass- } \\
\text { roots democracy } \\
\text { - Activities of Fede- } \\
\text { ral Government } \\
\text { attract attention of } \\
\text { regional and local } \\
\text { governments }\end{array}$ & $\begin{array}{l}\begin{array}{l}\text { Policy-makers } \\
\text { consider policy }\end{array} \\
\text { Need for policy: } \\
\text { - volunteering in } \\
\text { old age benefits } \\
\text { older people } \\
\text { Possibility of policy: } \\
\text { - Policy possible, } \\
\text { as pilot projects } \\
\text { show } \\
\text { Standing of the } \\
\text { policy: } \\
\text { - Policy desirable, } \\
\text { if it helps older } \\
\text { people } \\
\text { - Policy not } \\
\text { desirable, if } \\
\text { volunteering } \\
\text { benefits } \\
\text { governments } \\
\text { - Policy not } \\
\text { desirable, if } \\
\text { older people's } \\
\text { other activities not } \\
\text { valued }\end{array}$ & $\begin{array}{l}\text { Policy-makers } \\
\text { introduce policy }\end{array}$ \\
\hline
\end{tabular}

Fig. 2. Findings for Germany. The political discourse on older volunteers and the resulting policies.

realized under her successor, Hannelore Rönsch. This pilot project and its follow-up projects were at the center of discussions of the Federal Government on older volunteers: the attention older volunteers received culminated in the introduction of these projects, and the projects drew even more attention to older volunteers. In the states, policymakers started to pay more attention to older volunteers in the early 2000s. This date coincides with the start of the federal pilot project "Experiential Knowledge for Initiatives," which ran in cooperation with other levels of government (e.g. the state-level). At the local level, policy-makers usually paid attention to older volunteers, but not under the heading "support for older volunteers." When local policy-makers interacted with volunteer organizations, they often jointly considered all volunteers, without explicitly targeting the older age groups. This age-integrated view became obvious when local policy-makers interacted with senior representatives in their municipalities: The policy-makers primarily considered the senior representatives as engaged citizens, without qualifying them according to their age.

Older volunteers attracted the attention of German policy-makers for various reasons. Policy-makers at the local level mainly underlined the number and character of today's older people when they discussed older volunteers. They argued that the increasing number of older people pushes the idea of "activities and needs in old age" onto the political agenda. This argument corresponds to Hogwood and Gunn's (1984) statement that issues attract attention when they reach critical proportion. When talking about the character of today's older people, policy-makers at the local level usually pointed out that the new generation of older people is active and interested in volunteering. They also described the members of this generation as self-organized and opinionated, which strengthens grassroots democracy and, thereby leads to a new distribution of power.

The discussions at the regional and federal level were more elaborate than the ones at the local level. In these discussions, the idea that older volunteers attract the attention of policy-makers because such volunteers might be used as a replacement for retrenching welfare states is quite evident. An officer from the Federal Family Ministry (Bundesministerium fuer Familien, Senioren, Frauen und Jugend [BMFSFJ]), however, stressed that this was not the motivation for supporting older volunteers, it was merely a side effect. Moreover, German interviewees identified particular incidents that drew attention to older volunteers. First and foremost, those interviewees pointed to the International Year of Volunteers in 2001. Moreover, a former minister of the BMFSFJ named several scientific and popular science publications that had a comparable effect. Finally, the interviewees stated that personal preferences can also be a reason why policy-makers pay attention to older volunteers.

How German policy-makers think about policies for older volunteers

German policy-makers were interested in turning their attention to older volunteers into policies for several reasons. First, they saw the need to support older volunteers. This support is intended to encourage volunteering in later life 
and, thus, fulfill older people's needs for meaningful activities and social contact. Second, the pilot projects of the BMFSFJ convinced German policy-makers that policies for older volunteers are viable. Once the first pilot project was established, it served as a model for new support activities. This model function was intended by the BMFSFJ, which aimed to inspire action at the regional and local levels, where the BMFSFJ has no jurisdiction. Third, policies for older volunteers had good standing with the electorate and within political parties. When they attempted to help older people, for example by improving their well-being and extending their social networks, such policies were socially acceptable. However, when they were designed to benefit governments, for example by helping them to reduce costs or the need for public social services, they were frowned upon. Our interviewees explained that older people also frown upon policies that do not value the activities older people already engage in. For example, the BMFSFJ initiated a campaign featuring an old sofa with sunken cushions and the slogan: "Sie können mehr Spuren hinterlassen als eine Kuhle im Sofa" (You can leave more traces than just an imprint on a sofa cushion). Our interviewees described this slogan as derogatory and as rooted in an image of passive older people. They moreover reported that several interest groups of older people had voiced their concern about this slogan to the BMFSFJ.

\section{Policies for older volunteers in Germany}

Policies for older volunteers in Germany are mainly set by the federal government, and only to a lesser extent by state and local governments. The German federal government introduced policies for older volunteers in 1993 when it installed its first pilot project supporting volunteering in old age, a five-year program called "Agencies for Senior Citizens" ("Seniorenbüros", see Wienberg, 2009). It created agencies that inform older people about volunteering, and that establish contact between interested older people and organizations with volunteering opportunities. After the project was terminated, many of these agencies remained in operation under the auspices of municipalities and welfare associations. In fact, the project was so successful that municipalities and welfare organizations even founded numerous Agencies for Senior Citizens independent from the pilot project. Consequently, the number of these agencies increased from 44 at the beginning of the pilot project to about 240 in 2008.

Sometime after the "Agencies for Senior Citizens" pilot project ended, the federal ministry, the states, and several associations introduced a new pilot project supporting older volunteers. In place between 2002 and 2006, this new project was entitled "Experiential Knowledge for Initiatives" ("Erfahrungswissen für Initiativen" [EFI]). The federal ministry had developed the concept for EFI based on experiences with the first pilot project and on ideas from a group of policy advisors. Similar to the first pilot project, EFI also encouraged older people to volunteer. In contrast to the first pilot project, however, EFI sought to enable older people to develop their own volunteer projects (Bundesministerium fuer Familie, Senioren, Frauen und Jugend [BMFSFJ], 2005). After the EFI project ended, several EFI initiatives carried on with financial support from the states, municipalities, and welfare associations.

From 2005 to 2007, the BMFSFJ ran the pilot project "Self-organization of older people" ("Selbstorganisation älterer Menschen" [SÄM]). This project supported groups of older people that carried out tasks that were important to their municipality, such as service provision for other older people or running a public swimming pool. Compared to the previous pilot project, SÄM focused more strongly on the relevance of older volunteers for municipalities. At the time of writing, the ministry had not yet published an official evaluation of this project.

In 2008, which was the end of the time period we studied, the BMFSFJ launched a new project supporting older volunteers: "Active in old age" ("Aktiv im Alter"). This project encourages municipalities to install forums where citizens can discuss development possibilities for their municipality. Those forums are intended to facilitate citizens' movements and to help older people find an active role in society (BMFSFJ, 2009).

In addition to the support programs initiated by the federal ministry, there were several attempts of regional and local policy-makers to support older volunteers. However, these attempts usually aimed at supporting volunteers, independent of the volunteers' age. Older volunteers benefit from such efforts, but they are not defined as the target group. Therefore, older volunteers, policy-makers and project organizers rarely reflect on the connection between such general support programs and older volunteers. Moreover, our interviews revealed great local variation in support for older volunteers. Several interviewees stressed that such support is more common where governments attempt to strengthen civic culture in general. Those interviewees named the state of Baden-Württemberg as the example par excellence. In Baden-Württemberg, the social ministry is very supportive of volunteers. For example, it backed the establishment of cooperatives run by older people at the same time that the federal ministry introduced the pilot project "Agencies for Senior Citizens." Unfortunately, those cooperatives did not persist.

\section{Findings from Italy}

While volunteering is important in Italy, older volunteers rank low on political agendas there. Instead of focusing on older volunteers, Italian policy-makers focus on welfare organizations and on volunteers independent of their age. For an overview, see Fig. 3.

\section{How the topic attracts attention in Italy}

It Italy, policy-makers paid attention to older volunteers throughout our entire study period, from 1990 to 2008. Federal policy-makers usually mentioned older volunteers briefly when they discussed old age, but they discussed them in more detail when they spoke about volunteering. Regional and local policy-makers, in contrast, usually mentioned older volunteers only in discussions about volunteering. Most of the time, however, they did not divide volunteers into age groups. Additionally, when they spoke about volunteering, they often focused only on the outcome of volunteering, not 


\begin{tabular}{|c|c|c|}
\hline $\begin{array}{l}\text { Topic attracts } \\
\text { attention }\end{array}$ & $\begin{array}{l}\text { Policy-makers } \\
\text { consider policy }\end{array}$ & $\begin{array}{l}\text { Policy-makers } \\
\text { introduce policy }\end{array}$ \\
\hline $\begin{array}{l}\text { Participants attract } \\
\text { attention: } \\
\text { - Associations of } \\
\text { older volunteers: } \\
\text { increase visibility } \\
\text { and influence } \\
\text { Topic attracts } \\
\text { attention: } \\
\text { - Critical proportion } \\
\text { reached: older } \\
\text { people and older } \\
\text { volunteers } \\
\text { - Tackles question } \\
\text { about distribution } \\
\text { of power: older } \\
\text { volunteers as } \\
\text { social service } \\
\text { providers }\end{array}$ & $\begin{array}{l}\text { Need for policy: } \\
\text { - No need: there are } \\
\text { many older } \\
\text { volunteers } \\
\text { - Need for policy: } \\
\text { Older people } \\
\text { biggest resource } \\
\text { for volunteering } \\
\text { Possibility of policy: } \\
\text { - No targeted } \\
\text { policy possible } \\
\text { Standing of the } \\
\text { policy: } \\
\text { - Policy not } \\
\text { desirable, because } \\
\text { unnecessary } \\
\text { - Policy desirable, } \\
\text { because it could } \\
\text { gain votes }\end{array}$ & $\begin{array}{l}\text { Policies for all } \\
\text { volunteers }\end{array}$ \\
\hline
\end{tabular}

Fig. 3. Findings for Italy. The political discourse on older volunteers and the resulting policies.

on the volunteers themselves. A report in the bulletin of the Regional Council of Tuscany illustrates this point. In 1993, the president of the regional council of Tuscany, Paolo Benelli, attended a meeting of the regional council of AUSER. AUSER is the pensioners' association of the CGIL trade union, of which about 40000 members volunteered in 2008. The activities of AUSER volunteers range from providing transportation to frail older people to acting as school crossing guards. During the AUSER meeting, Benelli underlined the contribution the social services provided by AUSER had to their older users' health and social integration. However, he did not mention that the volunteers who were providing these services were older people themselves (Anonymus, 1993).

Our interviewees explained the attention older volunteers receive in several ways. First, the high number of older people draws attention to activities in old age, such as volunteering. Second, the high number of older volunteers makes older volunteers' opinions heard in political processes. Third, the organization of older volunteers in associations such as AUSER makes older volunteers especially visible and influential. As a social service provider, AUSER is often involved in regional and local consultation processes.

\section{How Italian policy-makers think about policies for older volunteers}

Although Italian policy-makers paid attention to older volunteers, they decided against policies for older volunteers. Our interviewees claimed that only potential electoral gains would motivate policy-makers to introduce such policies.
Beyond that, our interviewees named three explanations for the lack of policies. First, Italian policy-makers see no need to support older volunteers, because they consider volunteering common among older people. Only one political consultant and a regional policy-maker argued that support might be needed. Older people have a high potential for volunteering, which, according to these interviewees, should make them the primary target groups for strategies to strengthen the overall level of volunteering. Second, Italian policy-makers see only limited possibilities to explicitly support older volunteers. These policy-makers assume that older volunteers can best be supported through policies for volunteers of all age groups. Third, in the eyes of Italian policy-makers, policies for older volunteers have a low standing. Our interviewees argued that the high number of older volunteers makes policies for them unnecessary and would, consequently, be a mismanagement of time and resources. Age groups with few volunteers, such as youths, should be targeted instead.

\section{Policies for older volunteers in Italy}

In Italy, governments rarely introduce policies for older volunteers. Within our study period, only the 2008 national law "Urgent measures for economic development, simplification, competitiveness, the stabilization of public finances and tax harmonization" ("Disposizioni urgenti per lo sviluppo economico, la semplificazione, la competitività, la stabilizzazione della finanza pubblica e la perequazione Tributaria") falls within this category. This law allows civil servants to spend the last 
years before retirement working as volunteers in non-profit organizations instead of continuing their previous work. In exchange for volunteering, they continue to receive 50 to $70 \%$ of their salary (Decreto-Legge 112/2008). Yet, two interviewees remarked that this legislation is mostly symbolic and has little impact on the number of older volunteers.

However, older Italian volunteers largely benefit from policies for volunteering in general. The pensioners' associations of Italian trade unions, such as AUSER, bring together many older people-and among them many older volunteers. Because some of their activities resemble social services, local and regional governments sometimes address and support AUSER as a social service provider. Moreover, because these activities are carried out by volunteers, AUSER and similar associations also receive support from the Centri di Servizio per il Volontariato (CSV, Service Centers for Volunteering).

\section{Discussion and conclusions}

This article explores policies for older volunteers in Germany and Italy. It maps these policies and the discussions leading up to them. In doing so, this article enhances our knowledge of old age and of welfare states. On the one hand, it contributes to discussions on the image of old age, on older people's engagement as volunteers, and on the situation and activities of healthy older people. On the other hand, this article illustrates how policy-makers respond to population aging.

The findings reveal similarities and differences between Germany and Italy. Similarities are that policy-makers in both countries consider population aging an important topic, and that they pay attention to older volunteers. Differences lie in whether or not policy-makers introduce policies explicitly targeting older volunteers, and in their rationale for this decision. German policy-makers stressed the contribution of volunteering to older people's well-being and introduced policies for older volunteers. Italian policy-makers, in contrast, framed older volunteers as social service providers and decided to not single out specific age groups in their policies for volunteers. These findings suggest that the impact of population aging on society and the state differs across countries, with the welfare state design strongly shaping this impact. A comparison with previous research shows that the German approach resembles the American one, while the Italian decision resembles that of the Dutch (Baldock, 1999). These similarities between countries are not in line with the welfare state typology suggested by Esping-Andersen (1990). We, therefore, conclude that factors unrelated to the type of welfare state determine how policy-makers address older volunteers. Consequently, we suggest that scholars draw from the evidence collected, and not from Esping-Andersen's welfare state typology, when discussing policies for older volunteers.

The differences between the perspectives of German and Italian policy-makers draw attention to the role of framing in policy-making. Framing is the embedding of a topic in a broader debate (Béland, 2005). Our findings show that the framing of volunteering in old age strongly influences whether policy-makers want to become active in this area: a framing as "help for older people" puts policies into a positive light, but a framing as "a substitute for retrenching welfare states" puts policies into a negative light. This finding backs up Firbank (2011), who demonstrated that framing influences home-care policies in Canada. On the one hand, policy-makers need to pay attention to this finding when they consider the impact of population aging on welfare states. These policy-makers might consider the growing number of healthy older people a resource to welfare states, which they could try to tap by, for example, promoting volunteering in old age. However, such efforts might meet resistance because of the unpopular framing. Hence, the growing number of healthy older people might as well be a resource to welfare state, but it is a resource that is hard to steer. On the other hand, older people's interest groups can utilize the importance of framing (Beard \& Williamson, 2011). They can increase the impact of their efforts to promote policies for older volunteers by stressing the benefits of volunteering for older people's well-being and social inclusion.

In a broader perspective, our findings underline the importance of perceptions for policy-making. German and Italian policy-makers perceive the number of older volunteers differently. Although this number is higher in Germany than in Italy (Erlinghagen \& Hank, 2006), German policy-makers call it a sign that some older people volunteer, while Italian policy-makers consider the number of volunteers to be high. Moreover, German and Italian policy-makers perceive the tasks of governments differently when it comes to older volunteers. While German policy-makers underline the possibility of governments to be proactive and give encouragement to older volunteers, Italian policy-makers remark that governments should only be reactive and handle the possible failures of older volunteers. Those findings suggest that the impact of population aging on welfare states cannot be captured with statistics and a description of institutions alone. Instead, future studies would also need to explore country-specific perceptions and interpretations of those statistics and institutions. Moreover, this insight suggests that policies for old age should not be simply transferred from one country to another. Instead, they need to be adapted to country-specific perceptions and cultures.

Besides framing and perceptions, previous policies also shape how policy-makers handle the topic of older volunteers. The German federal government set up a pilot project supporting older volunteers in 1993. Once adopted, this choice seems to have perpetuated itself, because further projects with similar designs followed. Moreover, later pilot projects also involved regional and local governments, which pushed the topic of older volunteers up the political agendas of these governments. Finally, the pilot projects convinced policy-makers that support for older volunteers is feasible, which swayed their decisions in favor of support efforts. Italy, in contrast, first decided to support those volunteer organizations that provide social services, and it later on set up service centers supporting all volunteers. These activities shaped how Italian policy-makers frame discussions on older volunteers: they frame them either as discussions on social services, or as discussions on volunteering in general.

The observation on the influence of previous policies is consistent with the literature on historical institutionalism, which suggests that new policies build on existing ones (Pierson \& Skocpol, 2002; Thelen, 1999). Béland (2005) 
added that policy-makers also draw from existing ideas when implementing new policies. This interpretation suggests that older people's interest groups have a small window of opportunity if they want to push the topic of older volunteers on the political agenda. They need to pick up this topic when it emerges, and frame it right away as a question of old age policies. This way, they might influence policy-making in their favor. However, Giddens (1990, 1991) argues that persisting institutions and ideas lose some of their structuring function as societies move from modernity to post-modernity. During this social transition, persisting institutions and ideas are questioned, de-valued, modified, and supplemented with a variety of new ideas and institutions. Consequently, a new window of opportunity for shaping policies for older volunteers might open up.

This study also enhances our understanding of the situation of older people. First, there are country-differences in how attractive volunteering seems to older people. In countries such as Germany, where governments promote volunteering as self-fulfillment in old age, volunteering will be attractive to older people. In countries such as Italy, in contrast, where volunteers are considered as service providers and where grandparental childcare is essential for families, volunteering will seem a less attractive option for older people. Second, older people differ in how they are affected by policies for older volunteers. Older people's volunteering behavior varies, for example, with gender and level of socio-economic status (e.g. Erlinghagen, 2010). However, policies for older volunteers in Germany and Italy take an undifferentiated approach, not accounting for this variation. Hence, the policies will fit the situation of some older people, while they will be unsuitable for others. This conclusion is in line with Petriwskyj, Warburton, Everingham, and Cuthill (2012). Likewise, policies for older volunteers show only limited variation between regions, even though the regions differ in their histories and population structures, for example. The main driver for uniformity is that policies for older volunteers are strongly influenced by activities of the federal government, which gives different regions the same starting point for their policies. On the one hand, this statement applies to the infrastructure that the federal government creates, for example, through legislation, centers for volunteering, and pilot projects. This infrastructure shapes the activities of the regional governments. On the other hand, the statement applies to the concept of policies for older volunteers, which federal policy-makers create through their activities and discussions. This concept influences which extant activities within the regions are labeled as policies for older volunteers.

The findings of our study can inform policy-makers and older people's interest groups who strive to shape policies for older volunteers. Policy-makers and interest groups in the United States, for example, can deduce from this study that it would be best to set up programs or associations in which older people handle their own social problems. In the United States, policies for older volunteers have existed since the 1960s (Chambre, 1993), which means that the initial window of opportunity for framing this topic and picking the policy approach has already closed. Therefore, future policies for older volunteers will be most readily accepted if they stand in the tradition of extant policies. Utilizing this path-dependency, policy-makers could expand the scope of governmentally organized programs for older volunteers, and older people's interest groups could set up new associations that qualify for governmental support programs for older volunteers (Baldock, 1999). When doing so, policy-makers can best mobilize support by tapping into persistent ideas about the roles of older people, volunteers, and the welfare state. In the United States, the citizens themselves are mainly responsible for ensuring their own welfare (Esping-Andersen, 1990), and they believe that they can achieve this if they try hard enough (Alesina \& Glaeser, 2004). Therefore, policies for older volunteers will be particularly well received if they frame volunteering as a means for older people to take their well-being into their own hands, to stand up for themselves, and to solve social problems. However, whether or not these policies should account for social inequalities in volunteering behavior cannot be stated conclusively. While policies for older volunteers often do not address social inequalities, there are profound inequalities between, for example, social classes and ethnicities in the United States.

Despite its merits, our analysis holds some limitations. First, this study does not provide a detailed overview of the entire situation in Germany and Italy. Our findings show that there is variation at the regional and-especially-the local levels, which makes a complete inventory of policies for older volunteers a very extensive task. It would be a worthwhile task for future studies to chart the entire landscape of these policies at all levels of government. When doing so, these studies could additionally collect information on the budgets allocated to these policies and to the number of older volunteers each policy reaches. This way, researchers could determine the effectiveness of the policies and the policymakers' nominal commitment to these policies. Second, this article studies two countries only: Germany and Italy. This number is too low for judging how universal our findings might be. A comparison with previous research (e.g. Baldock, 1999; Warburton \& Cordingley, 2004; Warburton et al., 2007) shows that we confirmed some drivers for policies, such as the desire to increase older people's well-being. However, we also identified some new drivers, in particular the policy-makers' personal preferences and the selfperpetuating effects of policies. Future studies in additional countries might identify additional drivers for policies for older volunteers. Moreover, such studies could help to identify clusters of countries with similar approaches to policies for older volunteers.

Summing up, Germany and Italy pursue different policies for older volunteers. German policy-makers discuss volunteering as contributing to older people's well-being and facilitate that contribution by explicitly supporting older volunteers. Italian policy-makers mainly view volunteering as social service provision and support volunteers independent of their age. This finding highlights the importance of framing, perceptions, and path-dependencies for policymaking. It moreover suggests that social context will influence whether older people decide to volunteer. Whether or not policies for older volunteers emerge, therefore, depends as much on society and political traditions as on the characteristics of the older population. Likewise, the impact of population aging on society and welfare states does depend not only on the extent of the demographic shift, but also on social structures and political traditions. 
Consequently, researchers and practitioners need to consider country-specific characteristics such as culture and history in addition to statistics and theories when addressing population aging.

\section{Acknowledgments}

We thank the historical city archive of Frankfurt upon Main, the archive of the region of Tuscany, the Department of Social Affairs for the province Bolzano-Alto Adige, and the Fondazione Roma Terzo Settore for granting us access to their archives. We, moreover, thank our interviewees for their time and cooperation. Finally, we thank Takashi Yamashita, Dawn Carr, and two anonymous reviewers for their insightful comments and suggestions that helped improve this manuscript.

\section{References}

Alesina, A., \& Giuliano, P. (2010). The power of the family. Journal of Economic Growth, 15, 93-125.

Alesina, A., \& Glaeser, E. L. (2004). Fighting poverty in the US and Europe. A world of difference. Oxford: Oxford University Press.

Alscher, M., Dathe, D., Priller, E., \& Speth, R. (2009). Bericht zur Lage und zu den Perspektiven des bürgerschaftlichen Engagements in Deutschland [Report on the situation and perspectives of civic engagement in Germany]. Berlin: Bundesministerium fuer Familie, Senioren, Frauen und Jugend.

Anonymus (1993). Il ruolo del volontario dei servizi sociali [The role of voluntary social services]. Toscana - Consiglio Regionale, 9, 214.

Ascoli, U., Pavolini, E., \& Ranci, C. (2002). The new partnership: The changing relationship between state and the third sector in the scenario of new social policies in Italy. In U. Ascoli, \& C. Ranci (Eds.), Dilemmas of the welfare mix. The new structure of welfare in the era of privatization (pp. 135-164). New York: Kluver.

Ascoli, U., \& Ranci, C. (2002). The context and new social policies in Europe. In U. Ascoli, \& C. Ranci (Eds.), Dilemmas of the welfare mix. The new structure of welfare in the era of privatization (pp. 1-24). New York: Kluver.

Baldock, C. V. (1999). Seniors as volunteers: An international perspective on policy. Ageing and Society, 19, 581-602.

Barr, N. (2004). The economics of the welfare state. Oxford: Oxford University Press.

Bass, S. A., Caro, F. G., \& Chen, Y. -P. (Eds.). (1993). Achieving a productive aging society. Westport, CT: Auburn House.

Beard, R. L., \& Williamson, J. B. (2011). Social policy and the internal dynamics of the senior rights movement. Journal of Aging Studies, 25, 22-33.

Béland, D. (2005). Ideas and social policy: An institutionalist perspective. Social Policy and Administration, 39, 1-18.

Bonker, F., \& Wollmann, H. (1996). Incrementalism and reform waves: The case of social service reform in the Federal Republic of Germany. Journal of European Public Policy, 3, 441-460.

Borzaga, C. (2004). From suffocation to re-emergence: The evolution of the Italian third sector. In A. Evers, \& J. -L. Laville (Eds.), The third sector in Europe (pp. 45-62). Cheltenham: Edward Elgar.

Borzaga, C., \& Fazzi, L. (2011). Processes of institutionalization and differentiation in the Italian third sector. VOLUNTAS: International Journal of Voluntary and Nonprofit Organizations, 22, 409-427.

Bundesministerium für Familie, Senioren, Frauen und Jugend (2005). Fünfter Bericht zur Lage der älteren Generationen in der Bundesrepublik Deutschland [Fifth report on the situation of older generations in the Federal Republic of Germany]. Bonn: Bundesministerium für Familie, Senioren, Frauen und Jugend.

Bundesministerium für Familie, Senioren, Frauen und Jugend (2009). Aktiv im Alter [Active in old age]. Retrieved from. http://www.bmfsfj.de/ BMFSFJ/Service/Archiv/16-legislatur,did=129196.html (on February 11, 2011)

Deutscher Bundestag (2007). Enquete Kommission "Zukunft des bürger schaftlichen Engagements" [Study commission on the future of civic engagement]. Retrieved from. http://webarchiv.bundestag.de/cgi/ show.php? fileToLoad $=112 \& i d=1040$ (on May 11,2013 )

Chambre, S. M. (1989). Kindling points of light: Volunteering as public policy. Nonprofit and Voluntary Sector Quarterly, 18, 249-268.
Chambre, S. M. (1993). Volunteerism by elders: Past trends and future prospects. The Gerontologist, 33, 221-228.

Choi, N. G., Burr, J. A., Mutchler, J. E., \& Caro, F. G. (2007). Formal and informal volunteer activity and spousal caregiving among older adults. Research on Aging, 29, 99-124.

Decreto-Legge (112/2008). Disposizioni urgenti per lo sviluppo economico, la semplificazione, la competitività, la stabilizzazione della finanza pubblica e la perequazione Tributaria [Urgent measures for economic development, simplification, competitiveness, the stabilization of public finances and the equalization of taxes] of June 25, 2008.

Dekker, P., \& Van den Broek, A. (2005). Involvement in voluntary associations in North America and Western Europe: Trends and correlates 1981-2000. Journal of Civil Society, 1, 45-59.

Dery, D. (1984). Problem definition in policy analysis. Kansas: University Press of Kansas.

Dye, T. R. (2008). Understanding public policy. Upper Saddle River: Pearson.

Erlinghagen, M. (2010). Volunteering after retirement. Evidence from German panel data. European Societies, 12, 603-625.

Erlinghagen, M., \& Hank, K. (2006). The participation of older Europeans in volunteer work. Ageing and Society, 26, 567-584.

Esping-Andersen, G. (1990). The three worlds of welfare capitalism. Princeton: Princeton University Press.

Evers, A. (1995). Part of the welfare mix: The third sector as an intermediate area. Voluntas: International Journal of Voluntary and Nonprofit Organizations, 6, 159-182.

Evers, A., \& Laville, J. -L. (Eds.). (2004). The third sector in Europe. Cheltenham: Edward Elgar.

Evers, A., Pijl, M., \& Ungerson, C. (Eds.). (1994). Payments for care. A comparative overview. Aldershot: Avebury.

Firbank, O. E. (2011). Framing home-care policy: A case study of reforms in a Canadian jurisdiction. Journal of Aging Studies, 25, 34-44.

Fraser, J., Clayton, S., Sickler, J., \& Taylor, A. (2009). Belonging at the zoo: Retired volunteers, conservation activism and collective identity. Ageing and Society, 29, 351-368.

Fuller, S., Kershaw, P., \& Pulkingham, J. (2008). Constructing “active citizenship": Single mothers, welfare, and the logics of voluntarism. Citizenship Studies, 12, 157-176.

Giddens, A. (1990). The consequences of modernity. Cambridge: Polity Press.

Giddens, A. (1991). Modernity and self-identity. Self and society and in the late modern age. Cambridge: Polity Press.

Glaser, B. G., \& Strauss, A. L. (2006). The discovery of grounded theory: Strategies for qualitative research. New Brunswick: Aldine Transaction.

Hank, K., \& Erlinghagen, M. (2010). Dynamics of volunteering in older Europeans. The Gerontologist, 50, 170-178.

Hank, K., \& Stuck, S. (2008). Volunteer work, informal help, and care among the $50+$ in Europe: Further evidence for 'linked' productive activities at older ages. Social Science Research, 37, 1280-1291.

Haski-Leventhal, D., Meijs, L., \& Hustinx, L. (2010). The third-party model: Enhancing volunteering through governments, corporations and educational institutions. Journal of Social Policy, 39, 139-158.

Hogwood, B. W., \& Gunn, L. A. (1984). Policy analysis for the real world. Oxford: Oxford University Press.

Hollinger, F., \& Haller, M. (1990). Kinship and social networks in modern societies: A cross-cultural comparison among seven nations. European Sociological Review, 6, 103-124.

Hong, S. -I., Morrow-Howell, N., Tang, F., \& Hinterlong, J. (2009). Engaging older adults in volunteering. Conceptualizing and measuring institutional capacity. Nonprofit and Voluntary Sector Quarterly, 38, 200-219.

Howlett, M., Ramesh, M., \& Perl, A. (2009). Studying public policy cycles and policy subsystems. Oxford: Oxford University Press.

Jann, W., \& Wegrich, K. (2007). Theories of the policy cycle. In F. Fischer, G. J. Miller, \& M. S. Sidnet (Eds.), Handbook of public policy analysis (pp. 43-62). Boca Raton: CRC Press.

Jeppson Grassman, E., \& Svedberg, L. (1996). Voluntary action in a Scandinavian welfare context: The case of Sweden. Nonprofit and Voluntary Sector Quarterly, 25, 415-427.

Johnson, R. B., Onwuegbuzie, A. J., \& Turner, L. A. (2007). Toward a definition of mixed method research. Journal of Mixed Methods Research, 1, 112-133.

Kingdon, J. W. (1995). Agendas, alternatives, and public policies. Boston: Little, Brown and Company.

Kohli, M. (1991). Retirement and the moral economy of growing old: A historical interpretation of the German case. In M. Minkler, \& C. L. Estes (Eds.), Critical perspectives on aging: The political and moral economy of growing old (pp. 273-293). Amityville, NY: Baywood.

Kohli, M., \& Künemund, H. (1996). Nachberufliche Tätigkeitsfelder. Konzepte Forschungslagen - Empirie [Post-occupational fields of activity. Concepts state of research - empirics]. Stuttgart: Kohlhammer.

Komp, K. (2011). The political economy of the third age. In D. Carr, \& K. Komp (Eds.), Gerontology in the era of the third age (pp. 51-66). New York: Springer Publishing. 
Komp, K., \& Béland, D. (2012). Balancing protection and productivity: International perspectives on social policies for older people. International Journal of Social Welfare, 20, S1-S7.

Laslett, P. (1996). A fresh map of life: The emergence of the third age. Basingstoke: Macmillan.

Laville, J. -L. (2008). What is the third sector? From the non-profit sector to the social and solidarity-based economy. Theoretical debate and European reality. In C. Leggewie, \& C. Sachsse (Eds.), Soziale Demokratie, Zivilgesellschaft und Buergergesellschaft (pp. 203-228)Social democracy, civil society, and civic society (pp. 203-228). Frankfurt: Campus.

Leonard, R., \& Johansson, S. (2008). Policy and practices relating to the active engagement of older people in the community: A comparison of Sweden and Australia. International Journal of Social Welfare, 17, 37-45.

Li, Y., \& Ferraro, K. F. (2006). Volunteering in middle and later life: Is health a benefit, barrier or both? Social Forces, 85, 497-519.

Lynn, L. E., Jr. (2002). Social services and the state: The public appropriation of private charity. Social Service Review, 76, 58-82.

Mayring, P. (2008). Qualitative Inhaltsanalyse. Grundlagen und Techniken [Qualitative content analysis. Basic principles and techniques]. Weinheim: Beltz.

Minkler, M., \& Holstein, M. (2008). From civil rights to ... civic engagement? Concerns of two older critical gerontologists about a "new social movement" and what it portends. Journal of Aging Studies, 22, 196-204.

Morse, J. M. (2009). Mixing qualitative methods. Qualitative Health Research, 19, 1523-1524.

Mutchler, J. E., Burr, J. A., \& Caro, F. G. (2003). Leaving the paid workforce and volunteering in later life. Social Forces, 81, 1267-1293.

Pavolini, E., \& Ranci, C. (2008). Restructuring the welfare state: Reforms in long-term care in Western European countries. Journal of European Social Policy, 18, 246-259.

Petriwskyj, A., Warburton, J., Everingham, J. -A., \& Cuthill, M. (2012). Diversity and inclusion in local governance: An Australian study of seniors' participation. Journal of Aging Studies, 26, 182-191.

Pierson, P., \& Skocpol, T. (2002). Historical institutionalism in contemporary political science. In I. Katznelson, \& H. V. Milner (Eds.), Political science: State of the discipline (pp. 693-721). New York: W.W. Norton.

Putnam, R. D. (2000). Bowling alone. The collapse and revival of American community. New York: Simon \& Schuster.

Ranci, C., \& Montagnini, E. (2010). The impact of the commodification of social care on the role and identity of the third sector in Italy. In A. Evers, \& A. Zimmer (Eds.), Third sector organisations facing turbulent environments $-a$ comparative view on five European countries (pp. 107-126). Baden Baden: Nomos.

Ranci, C., Pellegrino, M., \& Pavolini, E. (2005). The third sector and the policy process in Italy: Between mutual accommodation and new forms of partnership. Third Sector European Policy Working Paper Nr. 4. London: London School of Economics and Political Science.

Sundström, G., Malmberg, B., Sancho Castiello, M., Del Barrio, E., Castejon, P., Angeles Tortosa, M., et al. (2008). Family care for elders in Europe: Policies and practices. In M. E. Szinovacz, \& A. Davey (Eds.), Caregiving contexts. Cultural, familial and societal implications. (pp. 235-267). New York: Springer.

Thelen, K. (1999). Historical institutionalism in comparative politics. Annual Review of Political Science, 2, 369-404.

United Nations (2009). World population ageing 2009. New York: United Nations.

Van den Heuvel, W. (1997). Policy towards the elderly: Twenty-five years of Dutch experience. Journal of Aging Studies, 11, 251-258.

Van Tienen, M., Scheepers, P., Reitsma, J., \& Schilderman, H. (2011). The role of religiosity for formal and informal volunteering in the Netherlands. Voluntas: International Journal of Voluntary and Nonprofit Organizations, 22, 365-389.

Vis, B., \& Van Kersbergen, K. (2007). Why and how do political actors pursue risky reforms? Journal of Theoretical Politics, 19, 153-172.

Walker, A. (2000). Public policy and the construction of old age in Europe. The Gerontologist, 40, 304-308.

Warburton, J., \& Cordingley, S. (2004). The contemporary challenges of volunteering in an ageing Australia. Australian Journal of Volunteering, 9, 67-74.

Warburton, J., Paynter, J., \& Petriwskyi, A. (2007). Volunteering as a productive aging activity: Incentives and barriers to volunteering by Australian seniors. Journal of Applied Gerontology, 26, 333-354.

Wienberg, C. (2009). 15 Jahre Seniorenbüros - Ein persönlicher Rückblick von Christian Wienberg [15 years of agencies for senior citizens - a personal review by Christian Wienberg]. Retrieved from. http://www.seniorenbueros. org/fileadmin/user_upload/Ver_ffentlichungen/15_Jahre_Seniorenbueros_C. Wienberg.pdf (on February 09, 2011)

Zimmer, A., \& Evers, A. (2010). How do third sector organizations deal with change? Perspectives from five countries in three policy fields. In A. Evers, \& A. Zimmer (Eds.), Third sector organisations facing turbulent environments - a comparative view on five European countries (pp. 7-24). Baden Baden: Nomos. 